\title{
HOW INDUSTRY REACTS TO SHOCKS: CASE OUT OF RUSSIAN CITIES
}

\author{
Khmeleva Galina Anatolievna ${ }^{1,2, a^{*}}$, Tyukavkin Nicholay Mihaylovich ${ }^{2}$, Agaeva \\ Liliya Kyabirovna ${ }^{2}$, Kurnosova Elena Alexandrovna ${ }^{2}$, Sviridova Svetlana \\ Viktorovna ${ }^{3}$ \\ ${ }^{1}$ Samara State University of Economics, Sovetskoi Armii str., 141, 443090 Samara, Russian \\ Federation \\ ${ }^{2}$ Samara National Research University, Academica Pavlova str., 1, 443010 Samara, Russian \\ Federation \\ ${ }^{3}$ Voronezh state technical university, Moskovsky Avenue, 14, 394026, Voronezh, Russian Federation \\ agalina.a.khmeleva@yandex.ru \\ *Corresponding author
}

\begin{abstract}
Research of reactions of the city economics has always been of great interest to scientists. Firstly, the analysis helps the policy developers to take efficient measures to solve managerial problems. Secondly, in the era of globalization cities are by right considered centres of concentration of the industrial and labour potential of the country. This research makes an attempt to analyze the employment pattern in the manufacturing and extractive industry sectors in the period of economic shocks, assess the influencing factors in the Russian cities varying in size and geographical location, using the shift share analysis. The received results show that the sector of extraction and processing of natural resources is growing notwithstanding low oil prices and the sanction policy, but the number of employed in the manufacturing industry is decreasing. An important conclusion for management is considerable impact of the local government on ensuring a favourable economic structure. This research may become a basis for a discussion on the scope of powers of the local government in municipalities varying in size and geographical locations. Research of the issue of leadership and responsibility for prosperity of cities as national activity centres arouses particular interest in the time of crists or external impacts such as sanctions. Developing countries with authoritarian regime place the main emphasis on the state policy measures while the role of local government is often limited to development of territory infrastructure, local handcrafts, service industry. May be there is a need to deploy a "two-gear model" of local government powers and give the leading cities a possibility to take over solution of issues relating to the change of economic structure, industrial sector development for future prosperity.
\end{abstract}

Keywords: shift share; cities; industry; sanctions; innovation; crisis.

JEL Classification: C21, L22, R11, R12, R5

\section{Introduction}

The Russian economics has lately been impacted by two important events: the economic crisis of 2008 and imposition of sanctions in 2014. Russia is currently under the influence of economic sanctions from a number of countries including the EU member states, the USA, Japan, Australia and Canada. The restrictions have mostly affected the banking, oil and defense sectors. However, the financial sector has also turned out to be sensitive to sanctions, especially in 2014-2015. According to the adviser to the president of Russia Sergey Glazjev, the damage 
inflicted on the Russian financial branch by the anti-Russian sanctions has amounted to 250 billion US dollars for two years The subject of sanctions attracts strong interest in the scientific sphere as the sanction consequences may have direct (indirect) influence, short-term and longterm effect (Hoskins, 1998; Hufbauer et al., 2007). "Hidden" factors such as sanctions lead to the increase of transaction costs of companies, shortage of investments and export in the regions (Zarova, 2015).

Analysis of scientific works and analytical data devoted to the impact of economic sanctions enables singling out the key areas of sanction impact on the industry. In particular, there is increase of the role of federal centre in the economic regulation aimed at levelling the consequences of economic sanctions for the regions. Moreover, the transregional and international links with the suppliers of products and services change under the impact of geopolitical transformations; the economic management structure and the labour market in the regions "adjust" depending on the vector of imposed sanctions. Research is usually carried out for the country as a whole, regions and companies while the city industry in the period of economic shocks, such as crisis and sanctions remains insufficiently examined. (Ahrend, 2005)

The purpose of the research is to analyze the employment pattern in the manufacturing and extractive industry sectors in the Russian cities, assess the factors influencing these industry sectors in conditions of economic shocks using the shift share analysis.

The objectives of the research are to justify the research methodology, collect statistical data on 98 large Russian cities for the period of 2009-2015, perofrm calculations, and give conclusions and recommendations.

The conclusions of this article are aimed at understanding what structural shifts take place and what factors (national, branch, regional, local) make the most powerful impact on these processes in cities varying in geographical location and size. It is important to make correct managerial decisions. That's why the conclusions of this article will be useful for politicians and business in making managerial decisions aimed at achieving prosperity of their cities.

The article reviews the industrial sector of the cities of North-West, Volga, Ural, Siberia and Far East federal districts. These are the regions the main labour potential of the manufacturing and extractive industry sectors of the Russian economy is concentrated in.

\section{Methodology}

Our research covers two key aspects: to assess the absolute change of the number of employed in the extractive and manufacturing sectors (1), to reveal and qualitatively assess the force of the factors influencing the employment pattern in these sectors from the standpoint of management at national, branch, regional and local levels (2).

The company employment pattern ratios are usually used to assess the absolute change of the number of employed (Ashmarina, et al. 2016, Oxenstierna \& Olsson, 2015) and we will keep in line with this general practice.

As a rule, the influencing factor assessment methodology is determined by the research objectives. However, application of general scientific methods such as analysis and synthesis goes without saying.

We follow the shift share model Artigeformalized by Edgar S. Dunn (1960) to review the impact of such factors as national economy tendencies, branch environment, regional economy changes. 
Artige and van Neuss (2015) determines shift share analysis as an accounting method aimed at determination of cumulative productivity gain of the region in reference to the average in the country whether it is the result of its economic structure and/or its sector growth rate.

Today there exist multiple modifications of this model. For example, Thomas R. Harris et al. (1994) use the dynamic shift share model to research the character of dynamics of the economy of Nevada and its districts before the recession of 1981-82 and 1990-1991. The shift share model enables researching the spatial effect (Nazara \& Hewings, 2004; Wang, 2010), international trade (Markusen et al., 1991; Kommersant, 2016), regional convergence (Esteban 2000), competitiveness of international tourism (Shi et al., 2007).

We keep researching economics using the four-factor shift share analysis model with a local factor to assess the force of influence of territorial competitiveness (Khmeleva \& Egorova, 2016).

The generalized four-factor shift share analysis model is as follows:

$\Delta l_{I}=l_{i, t}-l_{i, t-1}=N S_{i}+I M_{i}+R S_{i}+L S_{i}$,

where

$N S_{i}$ is national factor or effect of national growth;

$I M_{i}$ is branch factor or effect of regional proportion;

$R S_{i}$ is regional factor (region) or effect of regional competition;

$L S_{i}$ is local factor (local territory) or effect of territorial competitiveness.

The effect of national growth $\left(\mathrm{NS}_{\mathrm{i}}\right)$ is a part of change of the total employment in the country. The effect of industry dynamics $\left(\mathrm{IM}_{\mathrm{i}}\right)$ represents changes a region (city) would undergo if the analyzed industrial sector grew (or decreased) on the national scale. The effect of regional proportions of competition $\left(\mathrm{RS}_{\mathrm{i}}\right)$ represents the difference between the actual change of employment in the regional industry and the change of the similar national ratio. If the regional change vector corresponds to the national labour market tendencies, $\mathrm{RS}_{\mathrm{i}}>0$. The effect of territorial competitiveness $\left(\mathrm{LS}_{\mathrm{i}}\right)$ is a part of change of the regional employment and shows how the economy in the analyzed cities corresponds to the regional and national tendencies. The total of these four effects gives the actual change of employment in the regional industrial sector for the analyzed period of time.

Application of the shift share analysis method is justified as for the many years it is being used the method has proven its consistency (1), and enables singling out all factors necessary for research such as national, branch, regional, local (2). The main advantage of the shift share analysis is that it gives a possibility to solve the issue of singling out the local effect in change of the general structure of the occupied working places.

This research is unique as it uses the four-factor shift share analysis to review the manufacturing and extractive industry of the cities in five federal districts of Russia from before the crisis of 2008 to the introduction of economic sanctions in 2014 to analyze the consequences that have not been duly studied before. Moreover, our analysis goes "from bottom to top", i.e. we accumulate the data by separate cities to consolidate them and receive results on large territories such as federal districts. 


\section{Results}

\subsection{Types and sources of data}

The research covers 98 Russian cities of North-West, Volga, Ural, Siberia and Far East districts. The year of 2009 is the beginning period for calculations as we follow the logic that post-crisis structural changes already began on the labour market in the course of the year. The calculations include the whole period of 2009-2015. The information sources are publicly available data of the Russian Federal State Statistics Service on the average annual number of company employees split by activity types (exclusive of small businesses) under the Russian Classification of Economic Activities (OKVED 2) OK 029-2014.

The Russian territories significantly differ in population density. According to the official data of the Russian Federal State Statistics Service (2017) the average population density in Russia amounted to 8.57 persons per sq. km. The Chukotka Autonomous Region has the lowest population density among the constituent entities of the Russian Federation ( 0.07 persons per sq. km). The highest density is in the country capital - Moscow (4,834.31 persons per sq. km). Since the population density geography significantly varies depending on the region and city of the country, we have reviewed the structural shift dynamics in percentage in order to level the impact of differences of this ratio by regions. Apart from the analysis of the structure types by the manufacturing and extractive activity types, the cities are divided into the two following types:

- "regional centre" - administrative centre of the region;

- "periphery" - all other cities of the region.

It is commonly believed that the most active and professional part of the region population lives in the administrative centres of the region. At the same time, development of large cities and agglomerations facilitates migration from the peripheral territories. Gerasimenko (2012) also noted the increasing disproportion along the North-East - South-West line. In the opinion of the scientist the population migrated from the North zone comprising $50 \%$ of the USSR territory at the beginning of the 1990 s or about $66 \%$ of the territory of Russia and having the population of a little above 11 million people. In 1990s the resident population migrated from the Far East and Siberia districts which became deserted. However, in 2009-2015 there was no active flow of the employed population in Russia. It can only be noted that the number of the employed in the Volga district decreased $(-2.8 \%)$ at growth of this ratio in the central regions of the country $(+2.13 \%)$.

The researched 98 cities of the North-West, Volga, Ural, Siberia and Far East districts differ in the number of population and the level of economic development. There are leaders among the cities in terms of population (Samara, Nizhny Novgorod, Chelyabinsk, etc.), salary (Tyumen), small cities with low living standards and economic results (Kurgan, Veliky Novgorod, Pskov, etc.). Affiliation to various types by the development level enabled carrying out a benchmark analysis of structural shifts and making important conclusions for the politics.

\subsection{The manufacturing sector is reducing, outflow from the industrial sector is higher in the peripheral cities than in the administrative centres.}

Tab. 1 shows the results of structural shift calculation in the cities by the Manufacturing activity type. 
Table 1 Structural shifts in the cities by the Manufacturing activity type in 2009-2015,\%

\begin{tabular}{lllllll}
\hline Federal districts & $\begin{array}{l}\text { Activity } \\
\text { type in } \\
2015,\end{array}$ & LS & IS & RS & LS & Total \\
& & & & & \\
& thousand & & & & & \\
\hline All cities & 1923,087 & 1,54 & $-6,93$ & $-1,08$ & $-6,27$ & $-12,74$ \\
Far Eastern & 74,977 & 1,44 & $-6,84$ & $-2,07$ & $-0,52$ & $-7,99$ \\
Volga & 1029,497 & 1,61 & $-7,01$ & $-2,62$ & $-6,33$ & $-14,35$ \\
North-West & 120,389 & 1,44 & $-6,84$ & $-1,02$ & $-6,62$ & $-13,03$ \\
Siberian & 322,720 & 1,44 & $-6,84$ & $-0,32$ & $-7,31$ & $-13,02$ \\
Ural & 375,504 & 1,44 & $-6,84$ & 2,94 & $-6,18$ & $-8,63$ \\
Regional centers & 1259,154 & 1,44 & $-6,84$ & $-1,09$ & $-4,18$ & $-10,67$ \\
Far Eastern & 42,426 & 1,44 & $-6,84$ & $-3,49$ & 10,94 & 2,05 \\
Volga & 689,448 & 1,44 & $-6,84$ & $-2,12$ & $-2,79$ & $-10,31$ \\
North-West & 64,060 & 1,44 & $-6,84$ & $-5,32$ & $-8,60$ & $-19,31$ \\
Siberian & 247,839 & 1,44 & $-6,84$ & 0,11 & $-8,08$ & $-13,37$ \\
Ural & 215,381 & 1,44 & $-6,84$ & 2,71 & $-5,17$ & $-7,86$ \\
Total periphery & 663,933 & 1,70 & $-7,10$ & $-1,06$ & $-9,94$ & $-16,40$ \\
Far Eastern & 32,551 & 1,44 & $-6,84$ & $-0,60$ & $-12,46$ & $-18,46$ \\
Volga & 340,049 & 1,92 & $-7,32$ & $-3,49$ & $-12,52$ & $-21,41$ \\
North-West & 56,329 & 1,44 & $-6,84$ & 4,77 & $-3,97$ & $-4,60$ \\
Siberian & 74,881 & 1,44 & $-6,84$ & $-1,77$ & $-4,69$ & $-11,86$ \\
Ural & 160,123 & 1,44 & $-6,84$ & 3,25 & $-7,49$ & $-9,64$
\end{tabular}

Source: Calculated by the authors using the data of the Russian Federal State Statistics Service

\section{Regional cross section}

The table data show the decrease of the number of employed at the manufacturing enterprises in all districts.

The national and branch factors make approximately equal influence on the structural shifts in the reviewed regions. In the same way there are no significant differences in the influence of the national and branch factors on the peripheral cities and the regional centres.

The highest decrease rate is evidenced in the cities of the Volga Federal District although this is the region where significant industrial potential is concentrated. The reason lies in the outdated material and technical facilities of many enterprises of the manufacturing sector of this old industrial region. The number of the employed at the industrial enterprises decreased by $14.35 \%$ (or 173.263 thousand people) in the Volga Federal District in 2009-2015. The worst picture is in Nizhny Novgorod and Togliatti. The structure of the industrial sector economy has negative impact in all analyzed cities. A positive impact on the industrial sector development produced by the managerial decisions made by the regional authorities is seen in Orenburg, Yoshkar-Ola, Kazan, Cheboksary, Izhevsk and Ufa, and the same for the decisions of the city authorities in Samara, Orenburg, Saransk, Perm, Penza, Votkinsk, Novoulyanovsk, Arzamas, Oktyabrsky.

The industrial structure does not correspond to the contemporary tendencies in all cities of the North-West Federal District, which determined a $13.03 \%$ reduction of the number of the employed in this sector. The efforts of the regional authorities bring no result or have a low impact in most cases. An exception is Saint Petersburg, which is explained not only by the 
influence of the managerial decisions made by the regional authorities of the city region but also by the spatial effect of this centre of the monocentric city agglomeration centered around Saint Petersburg, the second largest Russian city region after Moscow.

Severodvinsk has the biggest outflow from the industrial sector enterprises due to the local factor impact (-1.689 thousand persons). The main industrial product manufacturers in Severodvinsk are shipbuilding and ship repair enterprises of the manufacturing industry entering United Shipbuilding Corporation, JSC. The factor of mono-profile economy structure in Severodvinsk oriented on shipbuilding and ship repair product manufacture makes a negative contribution ( -2.519 thousand persons). A positive impact of the national and regional factors is connected to the implementation of large shipbuilding and nuclear submarine construction projects for the Navy and a complex of state measures for mono-city rehabilitation. At the same time, the activity of the local authorities is unfortunately not making a positive impact yet on the Severodvinsk industrial sector development.

The main relative share in the economic structure of the cities of the Ural Federal District is occupied by the manufacturing enterprises; its reduction rate is lower than average in the country and is relatively equally distributed between the regional centres and the peripheral cities. The number of employees of the manufacturing enterprises in the cities of the Ural Federal District reduced by $8.63 \%$ or 35.46 thousand persons, the impact of the branch factor is negative, 28.1 thousand persons; the impact of the regional factor is positive, 12.1 thousand persons; the local factor decreased the resulting ratio by 25.38 thousand persons.

The number of employees of the manufacturing enterprises in the cities of the Siberia Federal District reduced by $13.02 \%$ or 48.322 thousand persons, the impact of the branch factor is negative, 25.368 thousand persons; the impact of the regional factor is positive, 1.19 thousand persons; the local factor decreased the resulting ratio by 27.108 thousand persons.

The number of employees of the manufacturing enterprises in the cities of the Far East Federal District reduced by $7.99 \%$ (or 6.513 thousand persons), the impact of the branch factor is negative, 5.571 thousand persons; the impact of the regional factor is positive, 1.69 thousand persons; the local factor decreased the resulting ratio by 0.425 thousand persons. Although the share of the manufacturing sector is lower than average in Russia, there is slight increase of the number of the employed in the regional centres (by 2.05\%) as distinguished from other regions. The number of the manufacturing sector company employees grew by more than 5 thousand persons in Petropavlovsk-Kamchatsky alone and by more than a thousand persons in Vladivostok.

Consolidation of data by the cities listed above gives a possibility to conclude that the most substantial reduction in the manufacturing industry sector takes place in the Volga Federal District, by $14.3 \%$ (pic. 3), followed by the North-West (without Saint Petersburg) and the Siberia Federal Districts. The industry labour potential in the Ural and Far East Federal Districts reduced by $8.6 \%$ and $8 \%$ accordingly.

\subsection{Mining}

Tab. 2 shows the results of structural shift calculation in the cities by the Mining activity type. 
Table 2 Structural shifts in the cities by the Mining activity type in 2009-2015, \%

\begin{tabular}{|c|c|c|c|c|c|c|}
\hline Federal diastricts & $\begin{array}{l}\text { Activity type in } 2015, \\
\text { thousand people }\end{array}$ & $\mathrm{LS}$ & IS & $\overline{\mathrm{RS}}$ & $\overline{\mathrm{LS}}$ & Total \\
\hline All cities & 142,972 & 1,44 & 0,33 & 13,61 & $-27,14$ & $-11,76$ \\
\hline Far Eastern & 3,863 & 1,44 & 0,33 & $-4,08$ & 32,95 & 30,63 \\
\hline Volga & 45,875 & 1,44 & 0,33 & 14,44 & 17,29 & 33,51 \\
\hline North-West & 7,446 & 1,44 & 0,33 & $-3,74$ & $-44,72$ & $-46,69$ \\
\hline Siberian & 22,379 & 1,44 & 0,33 & $-7,10$ & 16,12 & 10,79 \\
\hline Ural & 63,409 & 1,44 & 0,33 & 21,17 & $-52,91$ & $-29,96$ \\
\hline Regional centers & 39,428 & 1,44 & 0,33 & 8,43 & 18,14 & 28,33 \\
\hline Far Eastern & 3,863 & 1,44 & 0,33 & $-3,86$ & 51,93 & 49,84 \\
\hline Volga & 25,281 & 1,44 & 0,33 & 12,40 & 3,88 & 18,04 \\
\hline North-West & 1,738 & 1,44 & 0,33 & $-8,15$ & 8,43 & 2,05 \\
\hline Siberian & 5,684 & 1,44 & 0,33 & 6,13 & 83,62 & 91,52 \\
\hline Ural & 2,862 & 1,44 & 0,33 & $-0,48$ & 37,84 & 39,13 \\
\hline Total periphery & 103,544 & 1,44 & 0,33 & 14,83 & $-37,74$ & $-21,14$ \\
\hline Far Eastern & 0,000 & 1,44 & 0,33 & $-5,63$ & $-96,14$ & $-100,00$ \\
\hline Volga & 20,594 & 1,44 & 0,33 & 17,83 & 39,49 & 59,09 \\
\hline North-West & 5,708 & 1,44 & 0,33 & $-3,13$ & $-52,10$ & $-53,46$ \\
\hline Siberian & 16,695 & 1,44 & 0,33 & $-9,38$ & 4,50 & $-3,12$ \\
\hline Ural & 60,547 & 1,44 & 0,33 & 21,68 & $-55,02$ & $-31,57$ \\
\hline
\end{tabular}

Source: Calculated by the authors using the data of the Russian Federal State Statistics Service

According to the data of Tab. 2 the number of mining company employees in the reviewed cities increased by $30.63 \%$ in general, the highest growth rates are in the Volga Federal District (33.5\%), followed by the Siberia Federal District (10.79\%). Expansion of the mining sphere in the Volga Federal District is the result of the oil extraction and processing development in the Samara and Orenburg regions and the Republic of Bashkortostan over the recent years.

The Ural Federal District has a natural and resource potential unique in its capacity and variability, a developed industrial complex, powerful although unequally developed transport and energy infrastructure, a high export product share, qualified labour resources, a broad network of educational and research and development centres. The mining share in the Ural Federal District is more than twice the average ratios in the reviewed regions, although significantly reduced from $4.62 \%$ in 2009 to $3.42 \%$ in 2015 . Nefteyugansk, Surgut, Tyumen had the highest increase of the employed in the mining sector. A negative dynamics is characteristic of the traditional oil and gas production cities Nizhnevartovsk, Nyagan, Kogalym, Novy Urengoy. The number of the sector employees grew by 5.4 times in Tyumen, which eventually determined the predominance in the ratio growth.

The Siberia Federal District is characterized by high rates of mining sector development in the regional centres; the number of the employed has grown by $91.52 \%$ for the 6 previous years. The number of the employed in the manufacturing sector is reducing, although at a lower rate than average in the country. As a result, the share of employees in the manufacturing sector reduced by $2 \%$ which is partly compensated by the extractive sector but mostly by the trade and service sector expansion.

Among the cities of the Far East Federal District the number of working places in the extractive sector increased only in Yuzhno-Sakhalinsk. In absolute terms the number of the employed in the Mining companies increased by 2,295 persons or by 2.3 times facilitated by 
favourable local conditions. The city houses the offices of Exxon Neftegaz Limited, Sakhalin Energy, Gazprom, Rosneft (RN-Sakhalinmorneftegaz, LLC) which are operators and contractors of the Sakhalin-1 and Sakhalin-2 projects and the largest oil and gas projects of the Far East of the Russian Federation. It should be noted that Yuzhno-Sakhalinsk recovered its popularity thanks to the implementation of large projects including a group of projects for the development of raw hydrocarbon deposits at the continental shelf of the Sea of Okhotsk and the Sea of Japan and the Tatar Strait bordering the Island of Sakhalin. From 2008 the population increased by 18,947 persons or $10.8 \%$ and amounted to 193,669 persons in 2016.

Fig. 1 shows change of the number of the employed in the manufacturing and extracting industry in 2009-2015, \%

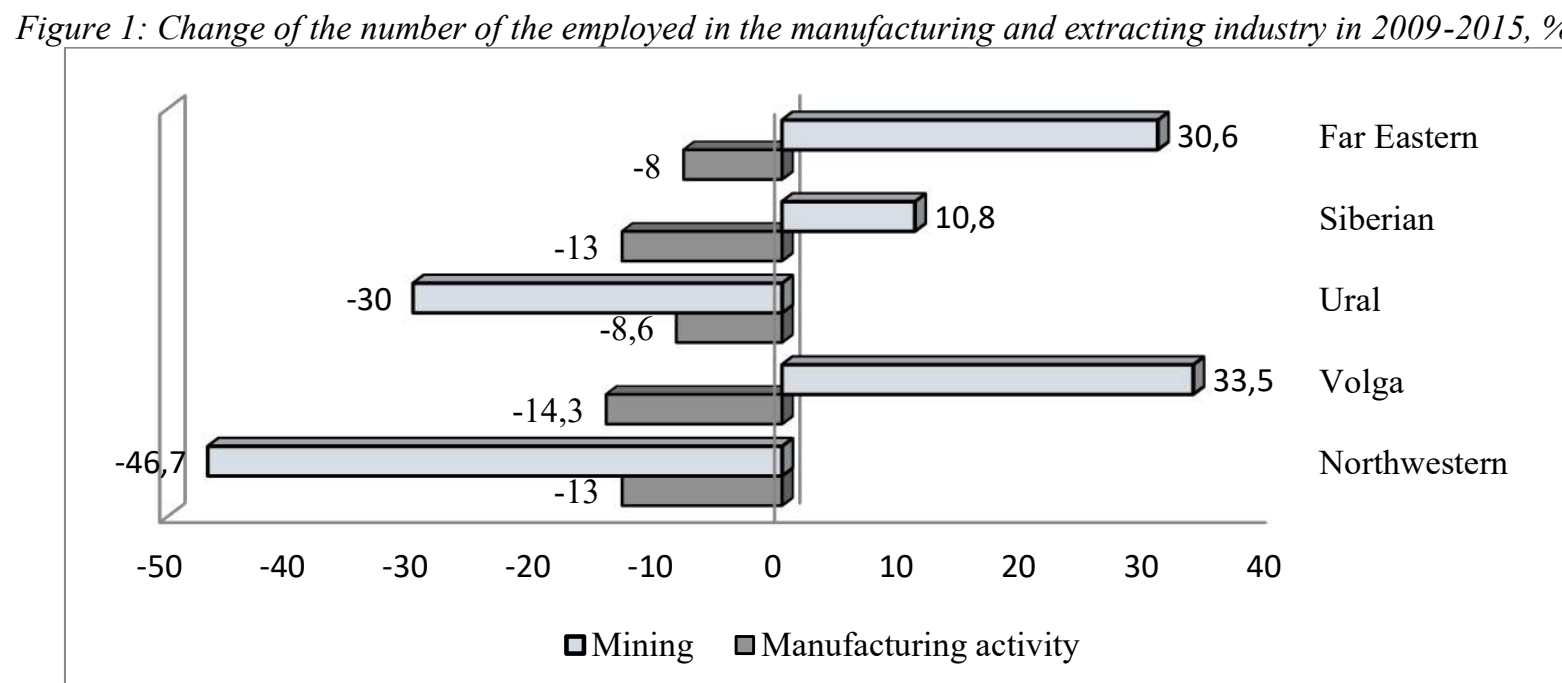

Source: Calculated by the authors using the data of the Russian Federal State Statistics Service

The Far East, Siberia and Volga Federal Districts evidence expansion of the mining sector while the North-West and Ural reduce the labour resources in the extractive industry. The manufacturing sector decreases on the whole in all cities of the federal districts.

\subsection{Force of impact of national, branch, regional and local factors}

The data array on 99 various cities that we use in the research gave us an opportunity to assess the correlation relationship between the national, branch, regional and local factors and the general change of the number of the employed in the industrial enterprises (Tab. 3).

Table 3 -Correlation coefficient between the factors and the general change of the number of the employed in the enterprises

\begin{tabular}{lllll}
\hline & NS & IS & RS & LS \\
\hline Manufacturing activity & $-0,671$ & 0,738 & 0,591 & 0,875 \\
Mining & $-0,625$ & $-0,625$ & $-0,540$ & 0,956 \\
Regional centers & $-0,992$ & 0,992 & 0,664 & 0,961 \\
Periphery & $-0,969$ & 0,977 & $-0,349$ & 0,989 \\
All cities & $-0,620$ & 0,652 & 0,421 & 0,842 \\
\hline
\end{tabular}

Source: Calculated by the authors using the data of the Russian Federal State Statistics Service

As the Tab. 3 shows, the impact of the local factor on change of the number of the employed in the enterprises is strong in general and by activity types ( $\mathrm{LS}=0.842>0.7)$ while the impact of the national, branch and regional factors is moderate (0.5 to 0.7$)$. The authors tend to explain the negative value of the correlation coefficient at NS by the opposite tendencies on the national level and in the reviewed cities. Nevertheless, this issue requires additional discussions as well 
Ekonomicko-manažérske spektrum / Economic and Managerial Spectrum

2017, Volume 11, Issue 1, pp. 74-86

as high correlation relationship between the local factor and the dynamics of the number of company employees.

The force of impact of the national, branch, regional and local factors by regions can be assessed using Fig. 2 and 3.

Figure 2(A-E): Structure of the factors impacting the Manufacturing Industry activity by federal districts

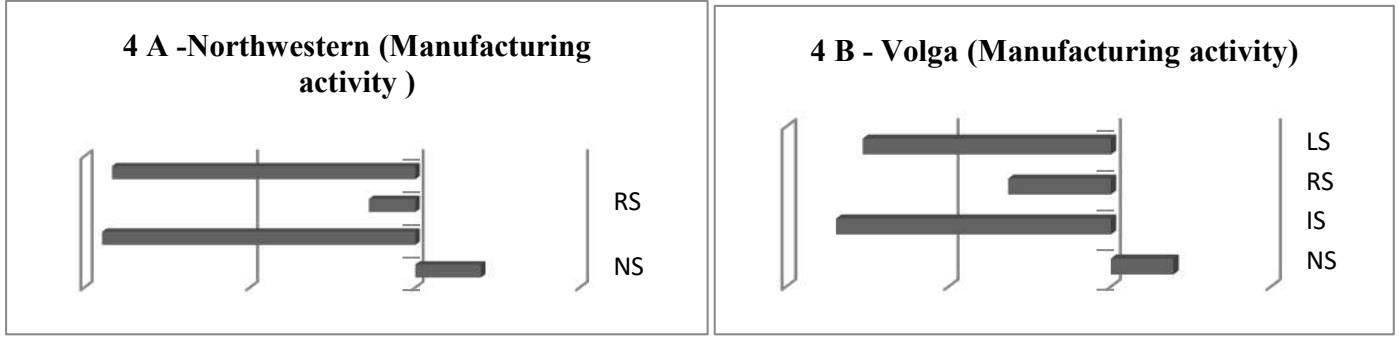

4 C - Ural (Manufacturing activity)
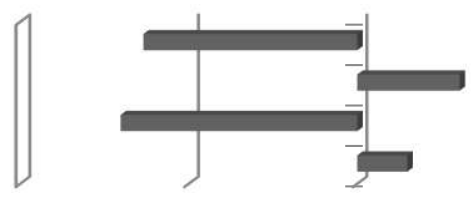

4 D - Siberian (Manufacturing activity)

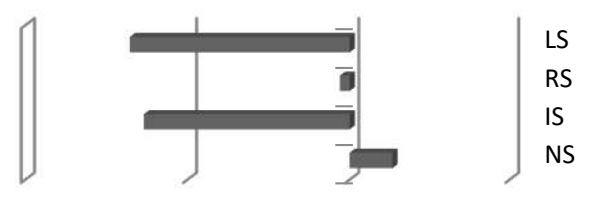

5 E - Far Eastern (Manufacturing activity)

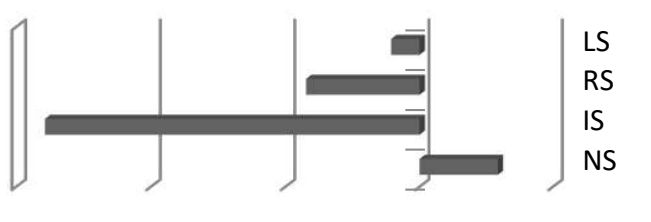

Source: Calculated by the authors using the data of the Russian Federal State Statistics Service

Figure 3(A-E): Structure of the factors impacting the Mining activity by federal districts
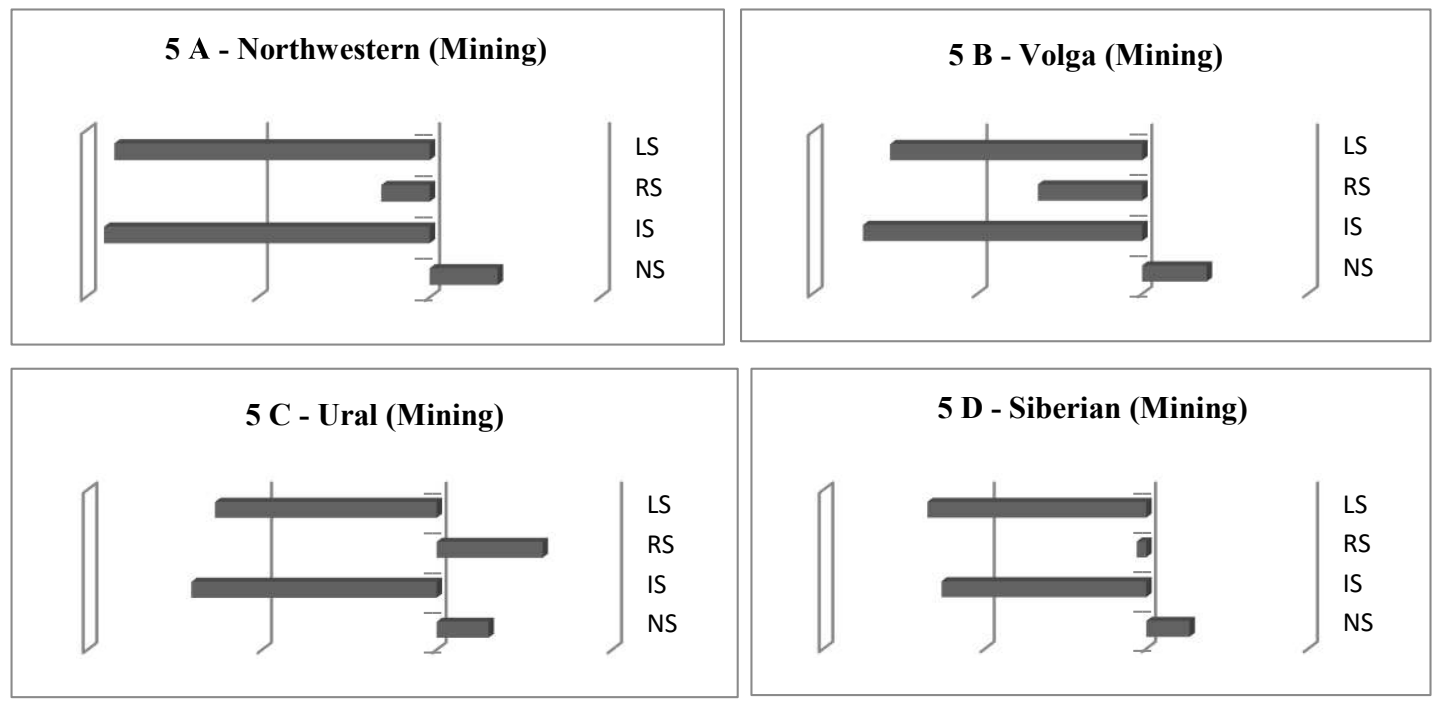


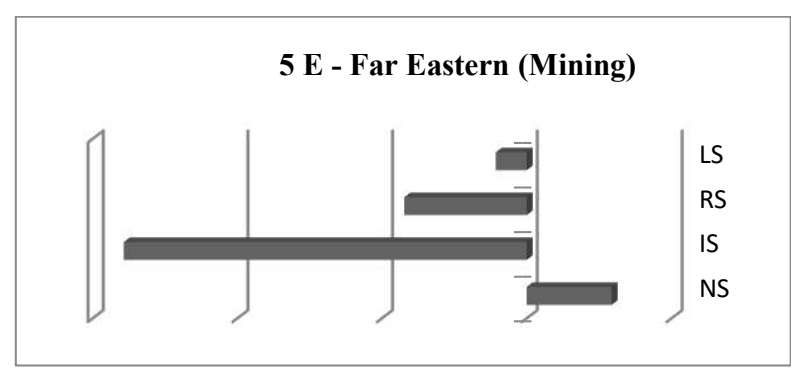

Source: Calculated by the authors using the data of the Russian Federal State Statistics Service

Fig. 2 and 3 give ground to conclude that the general dynamics of the number of the employed in the industrial sector makes although insignificant but positive impact in all presented districts. The branch (IS) and local (LS) factors produce the strongest impact. In the first case it is explained by the general reduction of the labour demand in the Russian industrial sector. The number of the employed in the Russian industrial sector decreased by $5.4 \%$ in the reviewed period. In the second case the reason lies in the unfavourable economic environment of the reviewed cities.

The accumulated effect of regional proportions in the cities is negative in all federal districts (RS). Having analyzed the force of the effect of regional proportions we can note that the economy of the cities of the Ural $(3-C)$ and Siberia $(3-D)$ Federal Districts much more corresponds to the national tendencies of materials sector potential development.

\section{Discussion}

This article confirms the conclusions of the previous research on the high role of the local factor. The importance of the local factor contribution for local territories such as cities is proven by the research in the Shift Share Regression (Blien at al., 2013). Seating and Loveridge (1994) tested the three-factor dynamic model and received high level of significance $(>0.9)$ for each of the effects - national economic growth, branch and regional factors. Other research works use the example of the three-factor model to conclude that the competitiveness component (regional factor in the three-factor model) is the most important from the regional development standpoint. The component (sometimes called competitive participation component) was interpreted as an indicator of the region competitiveness as compared to other regions in a specific economy sector. It means that it should be considered in any economic development plans (Zhao et al, 2006; Csáki \& Buchenrieder, 2013). However, our research has shown major differences between the impact of the national, branch, regional and local factors that contradicts, for example, the conclusions of Seating and Loveridge (1994). The four-factor model may need to be tested on the dynamic shift share analysis data to get specified results.

This research may serve as a basis for a discussion on the limits of powers of the local authorities and the impact of the factors on other sectors important for the economy, for example, on the innovation activity. There occur issues for further research such as the role of the local authorities, especially in the period complicated for the country economy, limits of powers for the cities varying in size and geographical location. The issue of benchmark analysis of the role of the local authorities in the periods of economic growth and decline is interesting as our research covers the two most significant economy shocks - the financial crisis of 2008 and the economic sanctions of 2014. Although there are research data proving that the local authorities more focused on the reform policy are capable of making a substantial contribution to increase attractiveness of their territory (Ahrend, 2012), new detailed research is required in 
this sphere. The issue on distribution of the factor impact on the innovation activity is still eligible for discussion.

\section{Conclusion}

We have received important theoretical and practical results in this article. To begin with, we have added the local effect to consider the impact of the territorial competitiveness on the economic growth. It gives a possibility to broaden the shift share analysis application sphere and analyze cumulative growth of production capacity of the local territories such as cities and agglomerations in respect to the country average values. Besides, there is a chance to perform benchmark analysis of various city types such as regional administrative centres and peripheries which increases the evidence base of the research conclusions regarding the economic growth factors and dynamics.

We have found out that the national branch environment effect equally extends to all cities and does not depend on their types or geographical locations. The national tendencies and the activity of the federal authorities in general make a positive influence on the growth of the number of working places in the industry (LS>0 in all analyzed federal districts).

An important conclusion for politics is that the basis for the Russian city economy development will remain production of hydrocarbons. The materials sector keeps being the basis of the Russian economic growth creating new economic stability threats in conditions of sanctions and hydrocarbon price reduction. The branch tendencies are also objectively of general character although make negative contribution to the dynamics of the number of working places in the industry. It can be linked to unsatisfactory economic structure in the Russian cities, general state of the industrial potential; in our opinion the force of this impact reaches critical values. The calculations confirm urgent need of structural reforms, solution of tasks of advanced scientific and technological development of the Russian economy. There is a need for the economic policy measures aimed at decreasing the dependence on raw materials.

The effect of regional proportions shapes under the influence of the regional business structure and shows the degree of correspondence of the regional labour market to the national proportions. Positive regional factor is characteristic of the cities with economy based on the mining sector. The economy of the cities of the Ural and Siberia Federal Districts much more corresponds to the national tendencies of material sector potential development. It turns out that the regions and cities aiming at the materials sector development are currently more competitive, which contradicts the declared state policy of innovation priorities in the country economy.

Outflow from the industry sector is higher in the peripheral cities than in the administrative centres. The effect of territorial competitiveness shows significant force of impact on the structural shifts in the extractive and manufacturing sectors in all federal districts apart from the Far East Federal District, proving that the role of the local authorities in the industry development is much higher than commonly believed. Maybe there is need of targeted approach to granting of powers to the local authorities and provision the most active city leaders with a possibility to solve more important questions than development of territory infrastructure, support of small business and local handcrafts. It resembles a "two-gear model" of powers where the first gear is a narrow basic list of powers. The second, higher gear represents the powers of the local authorities giving a chance to impact middle-size and large industrial enterprises. For example, provide preferences or tax benefits in case of their decline, which is important in the time of sanctions. It may be especially valuable for the large territories located 
far from the country centre. However, a warning should be made that in the countries with high level of corruption such as Russia it can be a trap as the chances of a fix up between the local authorities and business increase. Undoubted is the fact that the powers of the local authorities should not hinder but be aimed at development and prosperity of the central and peripheral cities irrespective of their geographical location.

\section{Acknowledgment}

This paper is an output of the science project No. 17-02-00340 "Innovative Development of Russian Regions in the Conditions of Sanctions: Impact Assessments, Differentiation and Opportunities for Advanced Development 2017-2018" of the Russian Foundation for Basic Research.

\section{References}

[1] Ahrend, R. (2005). Can Russia Break the "Resource Curse"? Eurasian Geography and Economics, vol. 46, no. 8, pp. 584-609. doi:10.2747/1538-7216.46.8.584

[2] Ahrend, R. (2012). Understanding Russian regions' economic performance during periods of decline and growth - An extreme bound analysis approach. Economic Systems, vol. 36, no. 3, pp. 426-443. doi: 10.1016/j.ecosys.2011.10.002

[3] Artige, L., \& van Neuss, L. (2015). A New Shift-Share Method. Growth and change, vol. 45, no. 4, pp. 667-683, doi: 10.1111/grow. 12065

[4] Ashmarina, S.I., Khasaev, G.R., Mantulenko, V.V., Kasarin, S.V., \& Dorozhkin, E.M. (2016). Methodical Bases for the Regional Information Potential Estimation. International Journal of Environmental and Science Education, vol. 11, no. 15, pp. 7715-7725.

[5] Blien, U., Eigenhüller, L., Promberger, M., \& Schanne, N. (2013). The Shift-Share Regression: An Application to Regional Employment Development in Bavaria. Applied Regional Growth and Innovation Models Advances in Spatial Science, pp. 109-137. doi:10.1007/978-3-642-37819-5_6

[6] Csáki, C., \& Buchenrieder, G. (2013). Effects of the financial and economic crisis on the rural landscape as well as the agri-food sector in Europe and central Asia. Society and Economy, vol. 33, no. 2, pp. 249-270. doi: 10.1556/SocEc.33.2011.2.2

[7] Dunn, E.S. (1960). A Statistical and Analytical Technique for Regional Analysis. Papers in Regional Science, vol. 6, no. 1, pp. 97-112. doi: 10.1111/j.1435-5597.1960.tb01705.x

[8] Esteban, J. (2000). Regional convergence in Europe and the industry mix: a shift-share analysis. Regional Science and Urban Economics, vol. 30, no. 3, pp. 353-364. doi:10.1016/s0166-0462(00)00035-1

[9] Gerasimenko, T. (2012). Prostranstvo sovremennoŭ Rossii: vozmozhnosti i bar'ery razvitiia (razmyshleniia geografov-obshchestvovedov). Moskva: Vuzovskaia kniga, pp. 17-21.

[10] Harris, T.R., Gillberg, C.B., Narayan, R., Shonkwiler, J.S, \& Lambert, D.K. (1994). A Dynamic Shift Share Analysis in Nevada Economy. Technical Report, UCED. [Online]. Available: reports/statewide/9495-06rpt.pdf 
[11] Hoskins, E. (1998). The Impact of Sanctions. A study of UNICEF's perspective.New York: UNICEF, Office of Emergency Preparedness.

[12] Hufbauer, G.C. (2007). Economic sanctions reconsidered. Washington, DC: Peterson Institute for International Economics.

[13] Khmeleva, G.A., \& Egorova, K.S. (2016). Structural shift in a city labor market: globalization and local effects. $16^{\text {th }}$ International Scientific Conference Globalization and Its Socio-Economic Consequences University of Zilina. Rajecke Teplice, Slovak Republic. $5^{\text {th }}-6^{\text {th }}$ October 2016. pp. 855-863.

[14] Kommersant. (2016). Glazev otsenil ubyitki ot sanktsiy v chetvert trilliona dollarov. [Online]. Available: https://lenta.ru/news/2016/03/15/damage/

[15] Markusen, A.R., Noponen, H., \& Driessen, K. (1991). International Trade, Productivity, and U.S. Regional Job Growth: A Shift-Share Interpretation. International Regional Science Review, vol. 14, no. 1, pp. 15-39. doi: 10.1177/016001769101400102

[16] Nazara, S., \& Hewings, G.J.D. (2004). Spatial Structure and Taxonomy of Decomposition in Shift-Share Analysis. Growth and Change, vol. 35, no. 4, pp. 476-490.

[17] Oxenstierna, S., \& Olsson, P. (2015). The Economic Sanctions against Russia: Impact and Prospects of Success, Stockholm: FOI.

[18] Russian Federal State Statistics Service (2017).

[19] Seating, A.C., \& Loveridge, S. (1994). Testing dynamic shift-share. Regional Science Perspective, vol. 24, no. 1, pp. 23-41.

[20] Shi, C., Jie., Z., Yang, Y., \& Zhang, Z. (2007). Shift share analysis on international tourism competitiveness: A case of Jiansu Province. Chinese Geographical Science, vol. 17, no. 2, pp. 173-178.

[21] Wang. J. (2010). A Dynamic Spatial Shift-Share Analysis of Regional Employment Change in China, SRSA Conference, Now Orland, USA.

[22] Zarova, E. (2015). Vliyanie sanktsiy na ekonomiku regionov: statisticheskaya otsenka differentsiatsii otklika. Statistics and challenges of our time. Moskow. Russia. pp. 194198.

[23] Zhao X.H., Liu X.S., \& Ma P.C. (2006). Shift-Share Analysis of Industrial Structure in Hebei Province. International Conference on E-Learning. E-Business, Enterprise Information Systems and E-Government, Hong Kong. 